\title{
Investigation of the histological structure of cochlea and corti under light and electron microscope
}

\author{
Koklea ve kortinin histolojik yapısının ışık ve elektron mikroskopu ile araştırılması
}

 \\ Pınar Bilgici'1(i), Mehmet Akif Somdaş² \\ ${ }^{1}$ Department of Histology and Embryology, Faculty of Medicine, Erciyes University, Kayseri, Turkey \\ ${ }^{2}$ Department of Otorhinolaryngology, Faculty of Medicine, Erciyes University, Kayseri, Turkey
}

\begin{abstract}
Objectives: This study aims to investigate the histological structure of the cochlea and organ of Corti of the ear under light and scanning electron microscope (SEM).

Materials and Methods: A total of eight Wistar albino rats (aging 4 month, weighing 300-350 g) were used in this study. The right cochlea was detected in glutaraldehyde with phosphate buffer to examine in SEM. For light microscopy, cochlea was fixed in $10 \%$ formaldehyde solution and then decalcified. The sections taken from the tissues were stained with hematoxylin $\&$ eosin to evaluate the histological structure of the cochlea and Corti.
\end{abstract}

Results: In light microscopic images, scala media, scala vestibuli, and scala tympani were easily selected. In the SEM images, only scala media region where the organ of Corti was located was examined. Three lines of the outer hair cells and one line of inner hair cells were observed in SEM images after the removal of the tectorial membrane. The Deiter's cells supporting the inner and outer hair cells were obvious with their plaque-like structures.

Conclusion: We believe that the acquired images would contribute to the literature in the determination of the pathological conditions which may occur in the cochlea and the cortical structure, when they are particularly supported by the hearing tests.

Keywords: Auditory hair cells, inner ear, organ of Corti.
$\ddot{O} Z$

Amaç: $\mathrm{Bu}$ çalışmada kulağın koklea ve korti organının histolojik yapısı $1 s ̧ ı k$ ve taramalı elektron mikroskobu (SEM) ile araştırıldı.

Gereç ve Yöntemler: Çalışmada toplam sekiz Wistar albino cinsi sıçan (yaş 4 ay, ağırlık 300-350 g) kullanıldı. Taramalı elektron mikroskobunda incelemek için sağ koklea fosfat tamponlu glutaraldehit içerisinde tespit edildi. Işık mikroskobunda, koklea \%10 formaldehit solüsyonuna alındı ve ardından dekalsifiye edildi. Dokulardan alınan kesitler hematoksilin-eozin ile boyanarak, koklea ve kortinin histolojik yapısı incelendi.

Bulgular: Işık mikroskop görüntülerinde, skala media, skala vestibuli ve skala timpani kolaylıkla seçildi. Taramalı elektron mikroskobu görüntülerinde, yalnızca korti organının bulunduğu skala media bölgesi incelendi. Tektoriyal membran kaldırıldıktan sonra, SEM görüntülerinde dış tüylü hücrelerin üç hattı ve iç tüylü hücrelerin bir hattı izlendi. İç ve dış tüylü hücreleri destekleyen Deiter hücreler, plak benzeri yapılar eşliğinde belirgindi.

Sonuç: Elde edilen görüntülerin, bilhassa işitme testleri ile desteklendiğinde, koklear ve kortikal yapılarda meydana gelebilecek patolojik durumların belirlenmesinde literatüre katkıda bulunacağı kanısındayız.

Anahtar sözcükler: İşitsel tüy hücreleri, iç kulak, korti organı.

Received: July 29, 2020 Accepted: August 29, 2020 Published online: October 05, 2020

Correspondence: Esra Balcıŏlu, MD. Erciyes Üniversitesi Tıp Fakültesi Histoloji ve Embriyoloji Anabilim Dalı, 38280 Talas, Kayseri, Türkiye. e-mail: esrabalcioglu79@hotmail.com

Yalçın B, Balcıoğlu E, Yay A, Özge Önder G, Bilgici P, Somdaş MA. Investigation of the histological structure of cochlea and corti under light and electron microscope. KBB Uygulamaları 2020;8(3):160-164. 
Hearing in humans relies on relatively few mechanoreceptor cells, and the cochlea contains approximately 3,400 inner hair cells (IHC) and 12,000 outer hair cells (OHC). ${ }^{[1]}$ For this reason, studies involving the induction of stem cells, gene transfer or potential support cells are carried out to discover ways for eliminate the degeneration that occurs in these cells, which play a primary role in hearing. ${ }^{[2,3]}$

Age, genetic factors, drug ototoxicity, and acoustic trauma are the main reasons of hearing loss. Although several factors which cause hearing loss are known, the cellular mechanism is still unclear. Long-term exposure to high-intensity noise initiates certain reactions at a cochlear level, particularly OHCs in the organ of Corti inducing apoptosis. ${ }^{[4]}$ It has been reported that OHCs, particularly in the basal turn of the cochlea damaged, ${ }^{[5]}$ $\mathrm{IHCs}^{[6]}$ and other cells of the cochlea, ${ }^{[7]}$ stria vascularis $(\mathrm{STV}),{ }^{[7]}$ and spiral ganglion have morphological and functional changes. ${ }^{[7,8]}$

In the present study, we aimed to evaluate the apical surface specializations of these aforementioned cells under light microscope and by scanning electron microscope (SEM).

\section{MATERIALS AND METHODS}

In this study, a total of eight Wistar albino rats (aging 4 month, weighing 300 to $350 \mathrm{~g}$ ) were used between November 2016 and October 2017. The right cochlea was removed under the anesthesia and detected in glutaraldehyde with phosphate buffer to examine in SEM. For light microscopy, cochlea was fixed in $10 \%$ formaldehyde solution and routine tissue followup steps were performed and decalcified (Table 1). The sections taken from the tissues were stained with hematoxylin and eosin to evaluate the histological structure of the cochlea and Corti (Table 2). The cochleas of the rats were taken. The inner ear canal was detected in glutaraldehyde for electron microscopy examination of the cochlear lumen after removal of bone tissue. Post-fixation was performed with $1 \%$ osmium tetroxide $(\mathrm{OsO} 4)$, then passed through the increased acetone series, and dried with a critical point dryer. Using a sputter coater, gold palladium applied used for imaging.

\section{RESULTS}

In both light and SEM images, it was determined that the cochlea formed 2.5 turns around the bone called modiolus spongiosa. Reissner's membrane (RM) and basilar membrane (BM) divide cochlea into three chambers. The chambers S. media (SM), S. vestibuli (SV), and S. tympani (ST), which were present in each transitional period, were easily selected in light microscopic images (Figure 1).

\begin{tabular}{|cccccc|}
\hline \multicolumn{5}{c|}{ Table 1 } \\
Routine tissue follow-up steps \\
\hline Step & Process & Time & Step & Process & Time \\
\hline 1 & Tap water & $1 \mathrm{~h}$ & 7 & Absolute alcohol & $1 \mathrm{~h}$ \\
2 & $50 \%$ alcohol & $1 \mathrm{~h}$ & 8 & Absolute alcohol & $1 \mathrm{~h}$ \\
3 & $70 \%$ alcohol & $1 \mathrm{~h}$ & 9 & Xylene & $20 \mathrm{~min}$ \\
4 & $80 \%$ alcohol & $1 \mathrm{~h}$ & 10 & Xylene & $20 \mathrm{~min}$ \\
5 & $96 \%$ alcohol & $1 \mathrm{~h}$ & 11 & Xylene & $20 \mathrm{~min}$ \\
6 & Absolute alcohol & $1 \mathrm{~h}$ & 12 & Liquid paraffin $\left(60^{\circ} \mathrm{C}\right)$ & $1 \mathrm{Night}$ \\
\hline
\end{tabular}

\begin{tabular}{|c|c|c|c|c|c|c|c|c|}
\hline \multicolumn{9}{|c|}{ Table 2} \\
\hline Step & Process & Time & Step & Process & Time (min) & Step & Process & Time (min) \\
\hline 1 & Oven $\left(60^{\circ} \mathrm{C}\right)$ & $2 \mathrm{~h}$ & 8 & Tap water & 2 & 15 & $80 \%$ alcohol & 1 \\
\hline 2 & Xylene I/II/III & $10 \mathrm{~min}$ & 9 & Hematoksilen & $5-8$ & 16 & $96 \%$ alcohol & 1 \\
\hline 3 & Absolute alcohol I/II & $5 \mathrm{~min}$ & 10 & Tap water & 5 & 17 & Ablolute A. I/II/III & 1 \\
\hline 4 & $96 \%$ alcohol & $5 \mathrm{~min}$ & 11 & Eozin & $3-5$ & 18 & Xylene I/II/III & 20 \\
\hline 5 & $80 \%$ alcohol & $5 \min$ & 12 & Tap water & 1 & 19 & Close & \\
\hline 6 & $70 \%$ alcohol & $5 \mathrm{~min}$ & 13 & $50 \%$ alcohol & 1 & & & \\
\hline 7 & $50 \%$ alcohol & $5 \mathrm{~min}$ & 14 & $70 \%$ alcohol & 1 & & & \\
\hline
\end{tabular}


In the SEM images, only SM region where the corti were located was examined. In light microscopic images, tectorial membranes, inner pillar cells (IPCs), and outer pillar cells (OPCs), IHCs, and OHCs, and Deiter's cells (DCs) were clear. Three lines of OHCs and one line of IHCs were observed in SEM images after the removal of the tectorial membrane. The DCs supporting the IHCs and $\mathrm{OHCs}$ were obvious with their plaque-like structures (Figure 2).

\section{DISCUSSION}

Studies on the structure of the hearing and balance organ ear have been done for a long time and are usually based on data from audiometric tests. This is due to the fact that the histological and electron microscopic appearance is difficult due to the bone labyrinth structure.
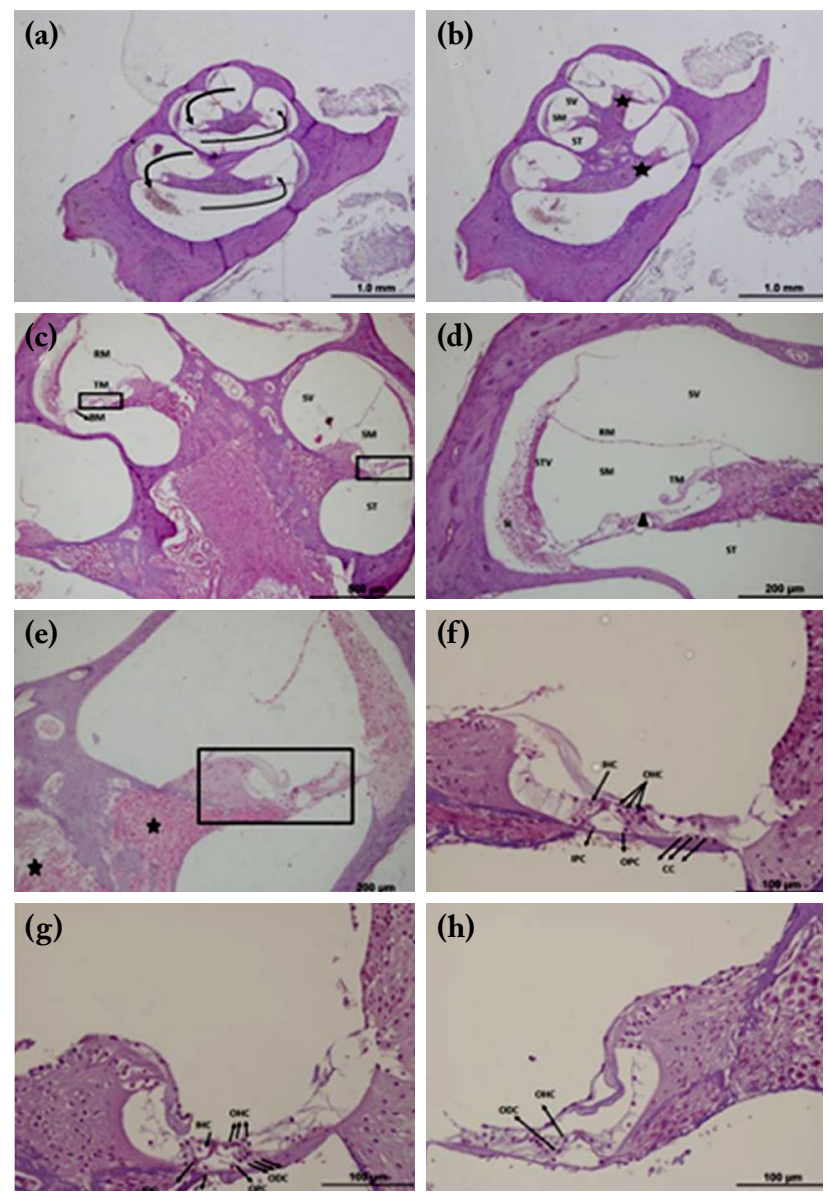

Figure 1. Light microscopic images of Corti.

SV: S.vestibuli; SM: Scala media; ST: Scala timpani; STV: Stria vascularis; SL: Spiral ligament; OHC: Outer hair cells; IHC: Inner hair cells; ODC: Outer deiter cell; IDC: Inner deiter cell; OPC: Outer pillar cells; IPC: Inner pillar cells; $\star$ : Cohlear nerve, $\square$ : Organ of corti; $\mathbf{\Delta}$ : Tunnel; BM: Basillar membrane; RM: Reissner's membrane; TM: Tectorial membrane; CC: Claudius cell.
In 1884, Gustav Retzius, a Swedish anatomist, presented surface preparations of the human auditory epithelium. ${ }^{[9]}$ Lim and Lane ${ }^{[10]}$ and Bredberg et al. ${ }^{[11]}$ were the first to reveal the fine surface structure of the mammalian organ of Corti using SEM.

Some factors such as genetic, bacterial/viral infections, ototoxic drugs, and age may lead to pathological changes in humans similar to rats. ${ }^{[12]}$ In particular, the sensory cell stereocilia have changes, and $\mathrm{OHC}$ and IHC degeneration and loss of these cell have been observed. ${ }^{[13]}$

In blast-exposed ears, cochlear pathology includes scar formation replacing dead hair cells, fused and damaged stereocilia and, in some extreme cases, separation of the organ of Corti from the basilar membrane. Majority of the hair cell loss was in the $\mathrm{OHC}$ region and usually in the middle or basal turn. Although hair cell loss was determined in the apical turn, the damage was less pronounced. ${ }^{[14]}$

Acoustic overstimulation of the cochlea generates free radicals and reactive oxygen species (ROS), which may induce OHC death. ${ }^{[15]}$ Elevated levels of ROS activate the upregulation of cochlear antioxidant enzyme activity and modulate glutathione, the
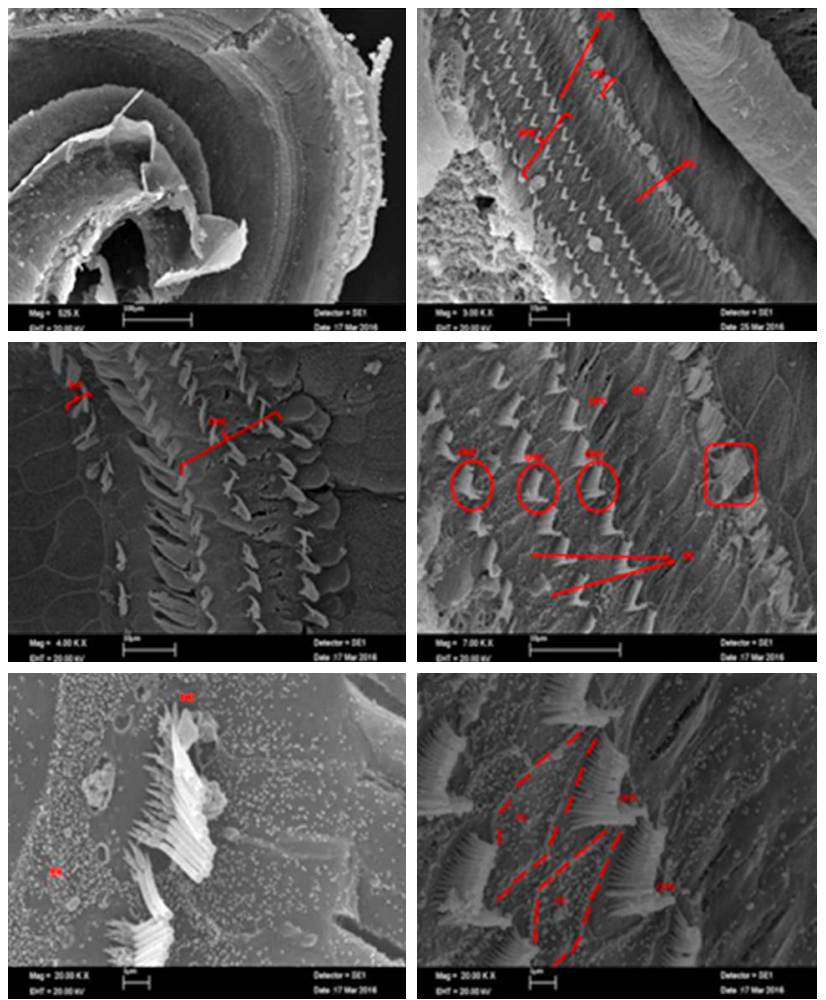

Figure 2. SEM images of Corti.

OHC: Outer hair cells; IHC: Inner hair cells; DC: Deiter cells; OPC: Outer pillar cells; IPC: Inner pillar cells. 
key antioxidant compound. ${ }^{[16]}$ Various agents with antioxidant properties have been shown to alleviate threshold shifts and hair cell loss after the exposure to damaging noise. ${ }^{[17]}$

Mammalian hair cells are believed to be terminally differentiated with no capacity to replenish, and their loss would inexorably produce permanent functional impairment, unless there is substantial redundancy. ${ }^{[18]}$ The doctrine that these cells are not renewed is based on animal experiments and the clinical experience that patients with sensorineural hearing loss do not regain function. ${ }^{[18]}$

Regeneration of hair cells in the vestibular system of mammals has been reported after gentamicin-induced hair cell loss. ${ }^{[18]}$ Similar findings were observed in the human utricle ${ }^{[19]}$ and vestibular hair cells following aminoglycoside-induced hair cell loss. ${ }^{[20]}$

If IHCs and $\mathrm{OHCs}$ die, hair cell elimination and scar formation are carried out by the neighboring supporting cells. The process containing the concurrent enlargement and sealing of the reticular lamina is named scarring; however, it differs from the general mechanism consisting of collagen formation after injury. ${ }^{[21]}$ Therefore, scarring between hair cell lines is an important criterion to evaluate any possible history of noise-induced hearing loss and these lesions can be differentiated from artifacts which may develop as a consequence of tissue autolysis. ${ }^{[21,22]}$

In conclusion, acquired images by light and SEM would contribute to the literature in the determination of the pathological conditions which may occur in the cochlea and the cortical structure, when they are particularly supported by the hearing tests.

\section{Declaration of conflicting interests}

The authors declared no conflicts of interest with respect to the authorship and/or publication of this article.

\section{Funding}

The authors received no financial support for the research and/or authorship of this article.

\section{REFERENCES}

1. Wright A, Davis A, Bredberg G, Ulehlová L, Spencer H, Bock $G$, et al. Hair cell distributions in the normal human cochlea. A report of a European working group. Acta Otolaryngol Suppl 1987;436:15-24.

2. Löwenheim H, Furness DN, Kil J, Zinn C, Gültig K, Fero ML, et al. Gene disruption of p27(Kip1) allows cell proliferation in the postnatal and adult organ of corti. Proc Natl Acad Sci U S A 1999;96:4084-8.
3. Bramhall NF, Shi F, Arnold K, Hochedlinger K, Edge AS. Lgr5-positive supporting cells generate new hair cells in the postnatal cochlea. Stem Cell Reports 2014;2:311-22.

4. $\mathrm{Hu} \mathrm{BH}$, Henderson D, Nicotera TM. Involvement of apoptosis in progression of cochlear lesion following exposure to intense noise. Hear Res 2002;166:62-71.

5. Stadnicki SW, Fleischman RW, Schaeppi U, Merriam P. Cis-dichlorodiammineplatinum (II) (NSC-119875): hearing loss and other toxic effects in rhesus monkeys. Cancer Chemother Rep 1975;59:467-80.

6. Barron SE, Daigneault EA. Effect of cisplatin on hair cell morphology and lateral wall Na,K-ATPase activity. Hear Res 1987;26:131-7.

7. Kohn S, Fradis M, Pratt H, Zidan J, Podoshin L, Robinson E, et al. Cisplatin ototoxicity in guinea pigs with special reference to toxic effects in the stria vascularis. Laryngoscope 1988;98:865-71.

8. Wright CG, Schaefer SD. Inner ear histopathology in patients treated with cis-platinum. Laryngoscope 1982;92:1408-13.

9. Retzius G. Das Gehororgan der Wirbelthiere. Stockholm: Samson and Wallin; 1884.

10. Lim DJ, Lane WC. Three-dimensional observation of the inner ear with the scanning electron microscope. Trans Am Acad Ophthalmol Otolaryngol 1969;73:842-72.

11. Bredberg G, Lindeman HH, Ades HW, West R, Engström H. Scanning electron microscopy of the organ of Corti. Science 1970;170:861-3.

12. Mills JH, Going JA. Review of environmental factors affecting hearing. Environ Health Perspect 1982;44:11927.

13. Bredberg G, Ades HW, Engstrom H. Scanning ElectronMicroscopy of normal and pathologically altered organ of Corti. Acta Otolaryng 1972;73(Suppl 301)3-48.

14. Ewert DL, Lu J, Li W, Du X, Floyd R, Kopke R. Antioxidant treatment reduces blast-induced cochlear damage and hearing loss. Hear Res 2012;285:29-39.

15. Yang WP, Henderson $\mathrm{D}, \mathrm{Hu} \mathrm{BH}$, Nicotera TM. Quantitative analysis of apoptotic and necrotic outer hair cells after exposure to different levels of continuous noise. Hear Res 2004;196:69-76.

16. Kopke R, Allen KA, Henderson D, Hoffer M, Frenz D, Van de Water T. A radical demise. Toxins and trauma share common pathways in hair cell death. Ann N Y Acad Sci 1999;884:171-91.

17. Coleman J, Huang X, Liu J, Kopke R, Jackson R. Dosing study on the effectiveness of salicylate/ $\mathrm{N}$-acetylcysteine for prevention of noise-induced hearing loss. Noise Health 2010;12:159-65.

18. Kawamoto K, Izumikawa M, Beyer LA, Atkin GM, Raphael Y. Spontaneous hair cell regeneration in the mouse utricle following gentamicin ototoxicity. Hear Res 2009;247:17-26.

19. Warchol ME, Lambert PR, Goldstein BJ, Forge A, Corwin JT. Regenerative proliferation in inner ear sensory epithelia from adult guinea pigs and humans. Science 1993;259:1619-22. 
20. Taylor RR, Jagger DJ, Saeed SR, Axon P, Donnelly N, Tysome J, et al. Characterizing human vestibular sensory epithelia for experimental studies: new hair bundles on old tissue and implications for therapeutic interventions in ageing. Neurobiol Aging 2015;36:2068-84.

21. Lim DJ, Dunn DE. Anatomic correlates of noise induced hearing loss. Otolaryngol Clin North Am 1979;12:493-513.

22. Morell M, Lenoir M, Shadwick RE, Jauniaux T, Dabin W, Begeman L, et al. Ultrastructure of the Odontocete organ of Corti: scanning and transmission electron microscopy. J Comp Neurol 2015;523:431-48. 